\title{
Consumenten
}

\section{Nieuwe regels voor de consumentenkoop en overeenkomsten met betrekking tot digitale inhoud}

\author{
Mr. dr. M.Y. Schaub*
}

Deze bijdrage belicht enkele aspecten van twee nieuwe richtlijnen op het terrein van consumentenbescherming, te weten Richtlijn (EU) 2019/770 (Richtlijn digitale inhoud) en Richtlijn (EU) 2019/771 (nieuwe Richtlijn consumentenkoop). Deze richtlijnen voorzien onder meer in regels die specifiek zijn toegesneden op digitale producten en goederen met digitale elementen.

Richtlijn (EU) 2019/770 van het Europees Parlement en de Raad van 20 mei 2019 betreffende bepaalde aspecten van overeenkomsten voor de levering van digitale inhoud en digitale diensten, PbEU 2019, L 136/1-27

Richtlijn (EU) 2019/771 van het Europees Parlement en de Raad van 20 mei 2019 betreffende bepaalde aspecten van overeenkomsten voor de verkoop van goederen, tot mijziging van Verordening (EU) 2017/2394 en Richtlijn 2009/22/EG, en tot intrekking van Richtlijn 1999/44/EG, PbEU 2019, L 136/28-50

\section{Inleiding}

Op 20 mei 2019 zijn twee nieuwe richtlijnen angenomen die van groot belang zijn voor het consumentenrecht. Het betreft Richtlijn (EU) 2019/770 (Richtlijn digitale inhoud) ${ }^{1}$ en Richtlijn (EU) 2019/771 (nieuwe Richtlijn consumentenkoop). ${ }^{2}$

De Richtlijn digitale inhoud voorziet in een thans bestaande lacune met betrekking tot overeenkomsten die

* Mr. dr. M.Y. (Martien) Schaub is universitair docent Transnational Legal Studies aan de VU Amsterdam.

1. Richtlijn (EU) $2019 / 770$ betreffende bepaalde aspecten van overeenkomsten voor de levering van digitale inhoud en digitale diensten, $\mathrm{PbEU}$ 2019, L 136/1-27.

2. Richtlijn (EU) $2019 / 771$ betreffende bepaalde aspecten van overeenkomsten voor de verkoop van goederen, tot wijziging van Verordening (EU) 2017/2394 en Richtlijn 2009/22/EG, en tot intrekking van Richtlijn 1999/44/EG, PbEU 2019, L 136/28-50. zien op de levering van digitale inhoud en diensten. ${ }^{3}$ De nieuwe Richtlijn consumentenkoop vervangt de oude Richtlijn consumentenkoop uit $1999 .{ }^{4}$ Ten opzichte van de oude Richtlijn consumentenkoop zijn de meeste regels in de kern gelijk gebleven; de regels zijn met name uitgebreid, onder meer met het oog op zaken die digitale elementen bevatten. Rechtspraak die onder de oude richtlijn is gewezen zal relevant blijven en sommige zaken zijn in die nieuwe richtlijn gecodificeerd. ${ }^{5}$ De bedoeling is dat de twee nieuwe richtlijnen elkaar aanvullen en op verschillende punten verwijzen de richtlijnen dan ook naar elkaar. Verder vullen de richtlijnen Richtlijn 2011/83/EU (Richtlijn consumentenrechten) aan. Lidstaten moeten de implementatiewetgeving voor beide richtlijnen uiterlijk 1 juli 2021 gereed hebben en de nieuwe regels moeten 1 januari 2022 in werking treden. ${ }^{6}$

In deze korte bijdrage zal ik enkele aspecten van de nieuwe richtlijnen uitlichten. ${ }^{7}$

3. Loos signaleerde in $\mathbf{2 0 1 1}$ dat een duidelijk juridische kader ten aanzien van overeenkomsten tot levering van digitale inhoud wenselijk zou zijn, zie M.B.M. Loos, 'Overeenkomsten tot levering van digitale inhoud', NTBR 2011/81.

4. Richtlijn 1999/44/EG betreffende bepaalde aspecten van de verkoop van en de garanties voor consumptiegoederen, PbEU 1999, L 171/12-16.

5. Bijvoorbeeld HvJ 17 april 2008, zaak C-404/06, ECLI:EU:C:2008:231 (Quelle) (zie art. 14 lid 4 Richtlijn (EU) 2019/771).

6. Art. 24 Richtlijn (EU) 2019/770 en art. 24 Richtlijn (EU) 2019/771.

7. Zie voor bespreking van enige aspecten van de nieuwe Richtlijn consumentenkoop ook: J.H.M. Spanjaard, 'Herziening consumentenrechten: verkenning van Richtlijn 2019/771', Contracteren 2019/3, p. 115-120. Zie voor een bespreking van beide richtlijnen ook: M.B.M. Loos, 'Herziening regelingen kooprecht en digitale inhoud aanstaande', TVC 2019/3, p. 106-116. 


\section{Van minimum- naar maximumharmonisatie}

Beide richtlijnen beogen, behoudens enkele uitzonderingen, maximumharmonisatie. ${ }^{8}$ Dat betekent dat het lidstaten niet is toegestaan bepalingen te handhaven of in te voeren die afwijken van de richtlijnen. Op dit punt verschilt de nieuwe Richtlijn consumentenkoop van de oude die in minimumharmonisatie voorzag. Met maximumharmonisatie kan een grotere mate van harmonisatie worden bereikt, wat gunstig kan zijn voor de grensoverschrijdende handel en daarmee de werking van de interne markt. De keuze voor maximumharmonisatie sluit aan bij de trend om in consumentenrichtlijnen maximumharmonisatie toe te passen, zie bijvoorbeeld de Richtlijn oneerlijke handelspraktijken, ${ }^{9}$ de Richtlijn consumentenkrediet, ${ }^{10}$ de Richtlijn pakketreizen ${ }^{11}$ en de Richtlijn consumentenrechten. ${ }^{12}$

Maximumharmonisatie roept de vraag op of met algemene verbintenisrechtelijke leerstukken een verdergaande bescherming mag worden geboden dan voorzien in de richtlijnen. ${ }^{13}$ Beide nieuwe richtlijnen bepalen dat zij geen afbreuk doen aan het recht van de lidstaten om te voorzien in regels betreffende algemene aspecten van het overeenkomstenrecht, zoals regels die zien op totstandkoming, geldigheid, nietigheid, de gevolgen van overeenkomsten, of schadevergoeding. ${ }^{14}$ Dat impliceert dat bijvoorbeeld de toepassing van de wilsgebreken niet geraakt wordt door de richtlijnen.

Met dwaling kan praktisch gezien vrijwel hetzelfde resultaat worden bereikt als ontbinding op grond van non-conformiteit. Als op grond van dwaling een verdergaande bescherming wordt geboden dan een consument op basis van de richtlijnen zou hebben, wordt daarmee de maximumharmonisatiedoelstelling ondergraven. ${ }^{15}$ Deze problematiek speelde onder de oude Richtlijn con-

8. Art. 4 Richtlijn (EU) 2019/770 en art. 4 Richtlijn (EU) 2019/771.

9. Richtlijn 2005/29/EG betreffende oneerlijke handelspraktijken, PbEU 2005, L 149/22-39.

10. Richtlijn 2008/48/EG inzake kredietovereenkomsten voor consumenten, PbEU 2008, L 133/66-92.

11. Richtlijn (EU) $2015 / 2302$ betreffende pakketreizen en gekoppelde reisarrangementen, PbEU 2015, L 326/1-33.

12. Richtlijn 2011/83/EU betreffende consumentenrechten, PbEU 2011, L 304/64-88.

13. Over deze problematiek zie bijvoorbeeld: T. Wilhelmsson, 'Full harmonization of consumer contract law?', Zeitschrift für Europäisches Privatrecht 2008/2, p. 226; hij wijst erop dat er een chaotische juridische situatie ontstaat wanneer onderdelen van het consumentenrecht geharmoniseerd worden zonder dat het algemene contractenrecht geharmoniseerd wordt. Zie ook C.A.N.M.Y. Cauffman, M. Faure en T. Hartlief, 'Het richtlijnvoorstel consumentenrechten: quo vadis?', Contracteren 2010/3, p. 74. C. Twigg-Flesner, The Europeanisation of contract law, current controversies in law, London: Routeledge Cavendish 2008, p. 53-54.

14. Art. 3 lid 10 Richtlijn (EU) $2019 / 770$ en art. 3 lid 6 Richtlijn (EU) 2019/771. Een nadere toelichting ten aanzien van wat door de nieuwe richtlijnen al dan niet wordt geraakt is te vinden in de overwegingen 12-15 bij Richtlijn (EU) 2019/770 en 18-20 bij Richtlijn (EU) 2019/771.

15. Hierover in het kader van Richtlijn 2005/29/EG V. Mak, 'De grenzen van maximumharmonisatie in het Europees consumentenrecht', NTBR 2011/77 en M.Y. Schaub, 'De invloed van de Wet OHP op dwaling', NTBR 2011/78. In het kader van informatieplichten bij financiële sumentenkoop niet, omdat die richtlijn minimumharmonisatie beoogt en dat laat aan de lidstaten de ruimte om meer bescherming te bieden.

Spanjaard stelt dat de nationale verbintenisrechtelijke leerstukken bij gevallen die onder de nieuwe Richtlijn consumentenkoop vallen ingevuld zullen moeten worden aan de hand van de normstelling van de richtlijn (en bijbehorende uitspraken van het Hof van Justitie). ${ }^{16}$ Het is natuurlijk koffiedik kijken, maar niet uitgesloten is dat het Hof van Justitie ooit zal bepalen dat de maximumharmonisatie niet omzeild kan worden door middel van de toepassing van algemene leerstukken op gevallen die binnen het geharmoniseerde terrein van de nieuwe richtlijnen vallen.

Uitgezonderd van de maximumharmonisatie van de nieuwe Richtlijn consumentenkoop zijn onder meer artikel 10 lid 3 en lid 6 (ansprakelijkheidstermijnen van de verkoper), artikel 11 lid 2 (termijn van het bewijsvermoeden), artikel 12 (klachtplicht), artikel 13 lid 7 (eigen schuld van de consument). Wat betreft de Richtlijn digitale inhoud zie bijvoorbeeld artikel 11 lid 2 waar is bepaald dat de aansprakelijkheidstermijn niet minder dan twee jaar mag zijn (en dus mag hier ook een langere termijn voor worden vastgesteld).

\section{Goederen, digitale inhoud en goederen met digitale elementen}

\section{Digitale inhoud en digitale diensten}

De nieuwe Richtlijn consumentenkoop ziet op de verkoop van goederen en goederen met digitale elementen en de Richtlijn digitale inhoud ziet op overeenkomsten met betrekking tot de levering van digitale inhoud en digitale diensten. ${ }^{17}$ Digitale inhoud is gedefinieerd als gegevens die in digitale vorm worden geproduceerd en geleverd. ${ }^{18}$ Een digitale dienst is een dienst die de consument in staat stelt gegevens in digitale vorm te creëren, te verwerken of op te slaan of toegang tot die gegevens te krijgen, of een dienst die voorziet in de mogelijkheid van het delen van gegevens of andere interactie met gegevens in digitale vorm die door de consument of door andere gebruikers worden geüpload of gecreëerd. ${ }^{19}$

Artikel 3 lid 4 en lid 5 Richtlijn digitale inhoud bevatten een opsomming van gevallen waarin de richtlijn niet van toepassing is en in de overwegingen wordt uitgebreid toegelicht wat wel en wat niet onder de richtlijn moet

diensten: C.A. Hage, 'Informatieplichten maken een wijs man?!', NTHR 2017/5, p. 265-271.

16. Spanjaard 2019, p. 118.

17. Over het toepassingsbereik van Richtlijn (EU) 2019/771 zie P.T.J. Wolters, 'Het toepassingsgebied van de richtlijn digitale inhoud en digitale diensten', TvC 2019/6.

18. Art. 2 sub 1 Richtlijn (EU) 2019/770 en art. 2 sub 6 Richtlijn (EU) 2019/771.

19. Art. 2 sub 2 Richtlijn (EU) 2019/770. De definities zijn ook opgenomen in art. 2 Richtlijn (EU) 2019/771. 
vallen. ${ }^{20}$ De richtlijn is bijvoorbeeld ook van toepassing indien de digitale inhoud is toegesneden op de specifieke eisen van de consument. ${ }^{21}$ De richtlijn is niet van toepassing op de levering van professionele diensten die langs digitale weg worden geleverd, zoals bijvoorbeeld vertaaldiensten, architectuurdiensten of adviesdiensten. ${ }^{22}$ Het enkele feit dat de consument een licentieovereenkomst met een derde moet sluiten is voor het bepalen van het toepassingsbereik van de nieuwe richtlijn niet relevant. ${ }^{23}$ De overwegingen specificeren verder dat het er niet toe doet hoe de digitale inhoud is geleverd en dat de richtlijn ook van toepassing is indien de digitale inhoud op een materiële drager wordt geleverd, mits de drager uitsluitend dient als drager van de digitale inhoud. ${ }^{24}$

Wat betreft de toepassing van de regels die voortvloeien uit de Richtlijn Consumentenrechten is wel van belang of de digitale inhoud op een materiële drager (zoals een CD of ander opslagmedium) wordt geleverd of niet. Ten aanzien van overeenkomsten op afstand met betrekking tot digitale inhoud die niet op een materiële drager wordt geleverd geldt dat de 14-dagen termijn van artikel 6:230o BW (dat is de bedenktijd) gaat lopen op de dag dat de overeenkomst wordt gesloten. ${ }^{25}$ Ten aanzien van digitale inhoud die op een drager wordt geleverd wordt onder het huidige recht uitgegaan van een koop en gaat de termijn lopen op de dag waarop de consument de drager ontvangt. ${ }^{26}$ Ten aanzien van de levering en het leveringsverzuim bij digitale inhoud geleverd op een materiële drager gelden in plaats van de regels van de Richtlijn digitale inhoud de artikelen 7:9, 7:10 en 7:19a BW, die voortvloeien uit de Richtlijn consumentenrechten. $^{27}$

De Richtlijn digitale inhoud is niet alleen van toepassing indien de digitale inhoud of dienst wordt geleverd tegen betaling van een prijs in geld, maar ook als de consument persoonsgegevens verstrekt. ${ }^{28}$ De richtlijn is weer niet van toepassing indien de consument aan reclame wordt blootgesteld uitsluitend om toegang tot digitale inhoud of een digitale dienst te krijgen. ${ }^{29}$

Uit overweging 12 bij de Richtlijn digitale inhoud valt op te maken dat deze richtlijn niet beoogt de juridische aard van de overeenkomsten met betrekking tot de levering van digitale inhoud of digitale diensten te bepalen en noemt als voorbeeld de vraag of dergelijke overeenkomsten een koopovereenkomst, een dienstenovereenkomst, een huurovereenkomst of een sui-generisover-

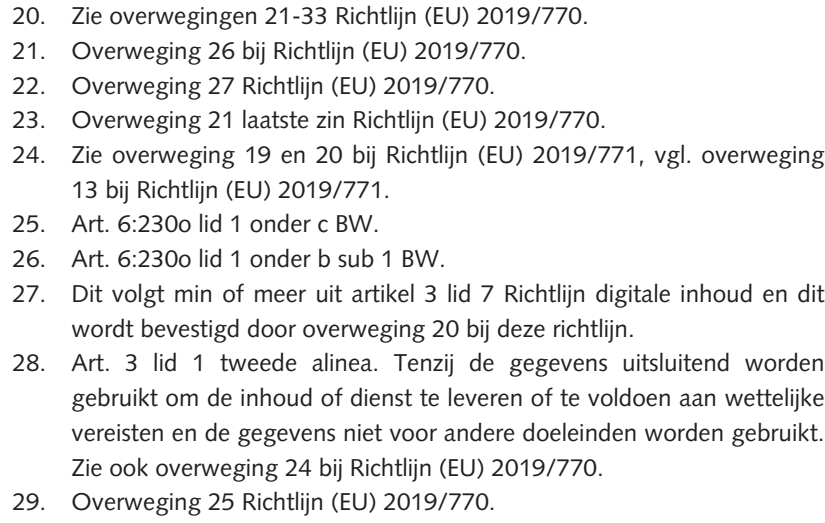

eenkomst omvatten. Wat betreft de kwalificatie als koopovereenkomst is dit opmerkelijk te noemen, omdat met de definities in de nieuwe richtlijnen en de uitgebreide toelichting hierop in de overwegingen juist beoogd lijkt te zijn duidelijk te maken onder welke omstandigheden de overeenkomst ten aanzien van de levering van digitale inhoud of diensten al dan niet kwalificeert als een koop.

Uit overweging 12 volgt dat dit enkel betrekking heeft op het toepassingsbereik van de nieuwe richtlijnen en dat betekent dat de overeenkomst die ziet op levering van digitale inhoud of diensten daarbuiten in voorkomend geval toch (of eigenlijk ook) als een koop kan worden aangemerkt. Gedacht kan worden aan toepassing van de regels van de Richtlijn consumentenrechten. Verder staat de kwalificatie van de overeenkomst als een overeenkomst voor de levering van digitale inhoud of digitale diensten er niet aan in de weg dat de overeenkomst tegelijkertijd als een ander type overeenkomst kan kwalificeren, zoals een overeenkomst van opdracht of een huurovereenkomst.

\section{Goederen en goederen met digitale elementen}

De nieuwe Richtlijn consumentenkoop definieert goederen als alle roerende lichamelijke zaken. Water, gas en elektriciteit wanneer zij gereed zijn gemaakt voor verkoop in een beperkt volume of in een bepaalde hoeveelheid worden ook beschouwd als goederen. ${ }^{30}$ Als gezegd vallen materiële gegevensdragers die enkel als drager dienen voor digitale inhoud niet onder de nieuwe Richtlijn consumentenkoop (ook al zijn dat strikt genomen zaken). ${ }^{31}$

Goederen zijn daarnaast alle roerende lichamelijke zaken waarin digitale inhoud of digitale diensten zijn verwerkt of die daarmee onderling verbonden zijn, op zodanige wijze dat het ontbreken van die digitale inhoud of die digitale dienst ertoe zou leiden dat de goederen hun functies niet kunnen vervullen (ofwel: goederen met digitale elementen). ${ }^{32}$ De nieuwe Richtlijn consumentenkoop specificeert dat het dan moet gaan om digitale inhoud en digitale diensten die worden meegeleverd met de goederen op grond van de koopovereenkomst, ongeacht of die digitale inhoud of de digitale dienst wordt geleverd door de verkoper of een derde. Bij twijfel wordt de digitale inhoud of digitale dienst geacht onder de koopovereenkomst te vallen. ${ }^{33}$

Ook het begrip goederen met digitale elementen is uitgebreid toegelicht in de overwegingen bij de nieuwe richtlijnen. ${ }^{34}$ Uit overweging 14 bij de nieuwe Richtlijn consumentenkoop volgt dat het kan gaan om digitale inhoud die reeds vooraf is geinstalleerd, maar ook die volgens de overeenkomst later wordt geïnstalleerd. Als voorbeelden worden genoemd: besturingssystemen, applicaties en alle andere software.

\footnotetext{
30. Art. 2 lid 5 Richtlijn (EU) 2019/771.

31. Art. 3 lid 4 onder a Richtlijn (EU) 2019/771

32. Art. 2 lid 5 Richtlijn (EU) 2019/771.

33. Art. 3 lid 3 Richtlijn (EU) 2019/771.

34. Zie overwegingen 14-16 bij Richtlijn (EU) 2019/771 en overwegingen 21 en 22 bij Richtlijn (EU) 2019/770.
} 
Uit overweging 15 bij de nieuwe Richtlijn consumentenkoop valt af te leiden dat de nieuwe Richtlijn consumentenkoop ook ziet op digitale inhoud of digitale diensten die worden verstrekt met goederen uit hoofde van de koopovereenkomst met betrekking tot die goederen. Als voorbeelden worden gegeven een smart-tv die is geadverteerd met een bepaalde videotoepassing, een smartphone die wordt geleverd met gestandaardiseerde alarmapplicatie of camera-applicatie en een smartwatch. Ook hier maakt het niet uit of de digitale inhoud wordt geleverd door de verkoper of een derde. Hieruit volgt dat digitale inhoud die niet noodzakelijk is voor het functioneren van het goed, maar die samen met het goed wordt geadverteerd en verkocht, ook onder de nieuwe Richtlijn consumentenkoop valt.

Helemaal zeker is dit niet, omdat in sommige gevallen ook gesproken zou kunnen worden van een combinatie van de levering van digitale diensten met apparatuur of andere diensten, ofwel van een bundeling van verschillende elementen in één overeenkomst. Volgens overweging 33 bij de Richtlijn digitale inhoud zal dan de Richtlijn digitale inhoud van toepassing moeten zijn op de elementen die bestaan in de levering van digitale inhoud of digitale diensten en vallen de andere elementen onder de desbetreffende relevante regelgeving. Als voorbeeld wordt genoemd het anbieden van digitale televisie in combinatie met de aankoop van elektronische apparatuur. ${ }^{35}$

\section{Wat maakt het uit?}

Op hoofdlijnen maakt het niet uit of de nieuwe Richtlijn consumentenkoop of de Richtlijn digitale inhoud van toepassing is. De conformiteitsnorm en de remedies die ter beschikking staan aan de consument zijn vrijwel gelijk en ten aanzien van updates bevatten beide richtlijnen bijvoorbeeld dezelfde regels. ${ }^{36}$

Op enkele punten is er wel verschil. Zo bepaalt de nieuwe Richtlijn consumentenkoop dat de lidstaten een kennisgevingsverplichting kunnen opnemen van ten hoogste twee maanden nadat de consument het gebrek heeft geconstateerd.$^{37}$ Thans geldt hier artikel 7:23 BW, waarbij geldt dat deze klachtplicht pas an de orde is als de consument het gebrek heeft ontdekt. Op basis van de nieuwe richtlijn is het toegestaan deze regel te behouden (mits gespecificeerd wordt dat de termijn voor de kennisgeving maximaal twee maanden is).

De Richtlijn digitale inhoud kent een dergelijk bepaling niet en uit overweging 11 blijkt bovendien dat het lidstaten niet is toegestaan om ten aanzien van digitale inhoud of digitale diensten te bepalen dat de consument binnen een bepaalde termijn moet klagen. ${ }^{38} \mathrm{Bij}$ de implementa-

35. Indien de digitale inhoud of dienst wordt aangeboden in combinatie met een nummergebaseerde interpersoonlijke communicatiedienst of internettoegangsdienst, dan zijn de bepalingen inzake de wijziging van digitale inhoud (art. 19 Richtlijn (EU) 2019/770) niet van toepassing; in plaats daarvan gelden de bepalingen van Richtlijn (EU) 2018/1972.

36. Wat betreft updates zie art. 8 lid 2 en 3 Richtlijn (EU) 2019/770 en art. 7 lid 3 en 4 Richtlijn (EU) 2019/771

37. Art. 12 Richtlijn (EU) $2019 / 771$.

38. Op het eerste gezicht lijkt het erop dat het de lidstaten vrij staat hier regels over op te nemen of te behouden, aangezien de Richtlijn Digitale tie zal er dus in voorzien moeten worden dat de klachtplicht en de onderzoeksplicht van artikel 6:89 BW niet langer zullen gelden bij digitale inhoud en digitale diensten. Indien er bij de implementatie van de richtlijnen voor wordt gekozen om artikel 7:23 BW te behouden zal de positie van de consument bij overeenkomsten ten aanzien van levering van digitale inhoud en diensten op dit punt gunstiger zijn.

Het is mogelijk dat de klachtplicht van artikel 7:23 BW voor de consumentenkoop wordt geschrapt. De nieuwe Richtlijn consumentenkoop bepaalt dat lidstaten een dergelijke regel kunnen handhaven of invoeren, schrappen kan dus ook. Dat zou vanuit het oogpunt van consistentie wenselijk kunnen zijn.

\section{Wie is de verkoper en de positie van tussenpersonen}

\section{Algemeen}

Beide richtlijnen zien op de situatie dat de aanbieder of de verkoper een professionele partij is en de afnemer of de koper een consument. ${ }^{39}$ Met andere woorden, de richtlijnen zien op zogenaamde b2c-relaties en niet op de situatie dat een consument de verkoper is, zoals c2bof c2c-relaties.

De nieuwe Richtlijn consumentenkoop definieert het begrip verkoper als iedere natuurlijke persoon of rechtspersoon, ongeacht of deze privaat of publiek is, die met betrekking tot onder deze richtlijn vallende overeenkomsten handelt, mede via een andere persoon die namens hem of voor zijn rekening optreedt in het kader van zijn handels-, bedrijfs-, ambachts- of beroepsactiviteit. ${ }^{40}$ De Richtlijn digitale inhoud definieert het begrip handelaar op dezelfde wijze. ${ }^{41}$

De tussenpersoon als verkoper

In het kader van de oude Richtlijn consumentenkoop heeft het Hof van Justitie geoordeeld dat een tussenpersoon onder omstandigheden als verkoper kan worden aangemerkt. ${ }^{42}$ De zaak betrof de verkoop van een auto door een particuliere verkoper via een professionele intermediair. Uit deze zaak volgt dat als een intermediair bij de verkoop van een zaak de indruk wekt de directe contractspartij te zijn of daar verwarring over schept, dat tot gevolg kan hebben dat op de intermediair de aansprakelijkheid komt te rusten van de verkoper in de zin

inhoud hier geen regels over bevat; uit overweging 11 blijkt evenwel iets anders. In de overwegingen 12 tot en met 17 wordt toegelicht op welke onderwerpen de lidstaten wel eigen regels mogen handhaven of opnemen.

39. Art. 2 lid 1 t/m 3 Richtlijn (EU) 2019/771 en art. 3 lid 1 Richtlijn (EU) 2019/770. Zie uitgebreid over de kwalificatie als consument dan wel als handelaar: M.Y. Schaub, 'Wie is consument?', TVC 2017/1, p. 30-40 en M.Y. Schaub, 'Wie is handelaar?', TvC 2019/2, p. 5-13.

40. Art. 2 sub 3 Richtlijn (EU) 2019/771.

41. Art. 2 sub 5 Richtlijn (EU) 2019/770.

42. HvJ 9 november 2016, zaak C-149/15, ECLI:EU:C:2016:840 (Wathelet). Over deze zaak zie: V. Mak, 'Noot bij HvJ EU 9 november 2016, C-149/15', TVC 2017/2, p. 88-91. 
van de oude Richtlijn consumentenkoop. Dit kan het geval zijn als de consument gemakkelijk op een dwaalspoor kan worden gebracht gezien de context waarin de verkoop plaatsvindt, omdat de tussenpersoon de afnemer niet naar behoren heeft geïnformeerd dat niet hij, maar een particulier de verkoper is. M.i. blijft deze uitspraak relevant onder de nieuwe Richtlijn consumentenkoop en zal op vergelijkbare wijze geredeneerd kunnen worden dat een tussenpersoon onder omstandigheden een handelaar is als bedoeld in de Richtlijn digitale inhoud.

\section{Een andere persoon die namens of voor rekening} van de verkoper optreedt

Zowel de definitie van het begrip verkoper als de definitie van het begrip handelaar bevat de zinsnede 'mede via een andere persoon die namens hem of voor zijn rekening optreedt'.

Deze zinsnede komt ook voor in de definitie van het begrip handelaar in de Richtlijn consumentenrechten. In dat kader heeft de Nederlandse wetgever dit geïnterpreteerd in de zin dat ook de vertegenwoordiger van een handelaar aangemerkt wordt als de handelaar, ongeacht de vorm van de vertegenwoordiging. ${ }^{43}$ Concreet betekent dit dat tussenpersonen ook verantwoordelijk zijn voor de verplichtingen die voortvloeien uit de Richtlijn consumentenrechten.

Indien de zinsnede in het kader van de nieuwe richtlijnen ook op die wijze wordt geimplementeerd zal dat meebrengen dat tussenpersonen (ongeacht de vorm van de vertegenwoordiging) verantwoordelijk zullen zijn voor de verplichtingen die voortvloeien uit de richtlijnen. Dit heeft dan overigens enkel gevolgen voor tussenpersonen die in naam van een achterman op treden. Tussenpersonen die in eigen naam (maar voor rekening van een achterman) handelen, zullen hier hoe dan ook als contractuele wederpartij van de consument verantwoordelijk voor zijn.

Het zou evenwel kunnen dat de richtlijnen met deze zinsnede niet zozeer beogen om de tussenpersoon te binden aan de verplichtingen die voortvloeien uit de richtlijnen, maar dat bedoeld is om de achterman aansprakelijk te kunnen houden, ongeacht de vorm van vertegenwoordiging. ${ }^{44}$ Beide varianten betekenen overigens een inbreuk op het Nederlandse vertegenwoordigingsrecht waarbij ofwel de achterman ofwel de tussenpersoon gebonden verantwoordelijk is, maar niet beide.

44. In die zin: C. Markou, 'Directive 2011/83/EU on consumer rights', in: A.R. Lodder en A.D Murray (red.), EU Regulation of E-commerce, Cheltenham: Edward Elgar Publishing 2017, p. 185. Zie ook: A. de VriesStotijn, 'Travel intermediaries and responsibility for compliance with EU travel law: a scattered legal picture', EuCML 2016/3, p. 121. De VriesStotijn signaleert dat de zinsnede 'al dan niet mede via een andere persoon die namens hem of voor zijn rekening optreedt' onduidelijk is en dat er indicaties zijn dat deze zinsnede bedoeld is om de achterman (ongeacht van de vorm van de vertegenwoordiger) verantwoordelijk te houden voor het gedrag van de vertegenwoordiger.

\section{Conformiteitseis}

De nieuwe richtlijnen bevatten beide een conformiteitseis die uiteen valt in een subjectieve en een objectieve component. ${ }^{45}$ De subjectieve component betreft de vraag of het geleverde voldoet aan wat er in de overeenkomst is afgesproken. De objectieve component bepaalt wat betreft goederen onder meer dat de geleverde goederen in ieder geval geschikt moeten zijn voor de doeleinden waarvoor goederen van hetzelfde type gewoonlijk zouden worden gebruikt en de eigenschappen heeft die de consument redelijkerwijs mag verwachten. De nieuwe conformiteitseis specificeert dat de conformiteit ziet op de hoeveelheid, de kwaliteit en andere kenmerken, zoals onder meer de duurzaamheid, functionaliteit, compatibiliteit en beveiliging. ${ }^{46}$ Voor zover er onder de huidige open conformiteitstoets twijfel kan zijn ten aanzien van de vraag of deze aspecten onderdeel vormen van de conformiteitstoets is die twijfel weggenomen. ${ }^{47}$

In de kern verschilt de nieuwe conformiteitseis niet van het huidige recht, maar wat opvalt is dat de nieuwe conformiteitseis een stuk gedetailleerder is uitgewerkt dan de huidige conformiteitseis die is neergelegd in artikel 7:17 BW, onder meer met het oog op digitale elementen van goederen. Zo bevat de nieuwe conformiteitseis specifieke regels ten aanzien van de updates die consumenten mogen verwachten. ${ }^{48}$

De nieuwe conformiteitsnormen bevatten verder de bepaling dat er geen sprake is van non-conformiteit wanneer de consument er ten tijde van de sluiting van de overeenkomst uitdrukkelijk van in kennis wordt gesteld dat een specifiek kenmerk van de goederen, de digitale inhoud of de digitale diensten afwijkt van de objectieve conformiteitsvereisten en de consument die afwijking uitdrukkelijk en afzonderlijk heeft aanvaard. ${ }^{49}$ Onder het huidige recht geldt voor de consumentenkoop op grond van artikel 7:17 lid $5 \mathrm{BW}$ dat een koper zich niet op non-conformiteit kan beroepen indien het gebrek ten tijde van het sluiten van de overeenkomst bekend was of redelijkerwijs bekend kon zijn. De nieuwe regels zijn een aanzienlijke aanscherping van dit punt, want de consument moet de afwijking van de objectieve conformiteitseis uitdrukkelijk en afzonderlijk aanvaarden. Volgens overweging 49 bij de Richtlijn digitale inhoud kan deze uitdrukkelijke aanvaarding verkregen worden door middel van het aanvinken van een hokje of door een knop of soortgelijke functie te activeren. In de nieuwe Richtlijn consumentenkoop is

45. Zie art. 6 tot en met 10 Richtlijn (EU) $2019 / 771$ en art. 5 tot en met 9 Richtlijn (EU) 2019/771.

46. Art. 7 lid 1 onder d Richtlijn (EU) 2019/771

47. Verbruggen en Wolters signaleren dat onder de huidige open normen van het consumentenrecht onzekerheid bestaat ten aanzien van de vraag waartoe consumenten gerechtigd zijn als het gaat om cybersecurity van de door hen aangeschafte digitale producten, zie P.W.J. Verbruggen en P.T.J. Wolters, 'Consument en Cybersecurity. Een agenda voor Europese harmonisatie van zorgplichten', TvC 2017/1, p. 20.

48. Art. 7 lid 3 en 4 Richtlijn (EU) $2019 / 771$ en art. 8 lid 2 en 3 Richtlijn (EU) $2019 / 770$

49. Art. 8 lid 5 Richtlijn (EU) 2019/770 en art. 7 lid 5 Richtlijn (EU) 2019/771. 
niet toegelicht hoe de uitdrukkelijke aanvaarding vorm zou moeten krijgen. ${ }^{50}$

Voor digitale inhoud en digitale diensten bestaat onder het huidige recht nog geen specifieke conformiteitseis. De vraag of het geleverde voldoet is daarmee op dit moment een vraag die volledig moet worden beantwoord op basis van uitleg van de overeenkomst. De Richtlijn digitale inhoud breidt dit uit met een objectieve component die bepaalt dat de digitale inhoud of dienst in ieder geval geschikt moet zijn voor de doeleinden waarvoor digitale inhoud of digitale diensten van hetzelfde type gewoonlijk worden gebruikt. De digitale inhoud of dienst dient verder te beschikken over de hoeveelheid, kwaliteit en prestatiekenmerken - onder meer met betrekking tot functionaliteit, compatibiliteit, toegankelijkheid, continuiteit en veiligheid - waarover digitale inhoud of diensten van hetzelfde type gewoonlijk beschikken. ${ }^{51}$ De verwachtingen van de consument zijn daarmee niet langer enkel afhankelijk van wat er in de overeenkomst is bepaald. In de overwegingen wordt nog gesignaleerd dat een schending van de Algemene verordening gegevensbescherming ${ }^{52}$ naargelang de omstandigheden van het geval ook geacht kan worden een conformiteitsgebrek in te houden. ${ }^{53}$

\section{Duur van de aansprakelijkheid}

Een verkoper is jegens de consument aansprakelijk voor conformiteitsgebreken aan goederen die aan het licht komen binnen twee jaar na de levering. Dit geldt ook bij koopovereenkomsten met betrekking tot goederen met digitale elementen waarbij de overeenkomst voorziet in een verplichting tot continue levering van digitale inhoud of diensten gedurende een bepaalde periode. Het staat er niet bij, maar kennelijk wordt bedoeld dat dit ook geldt indien die periode korter is dan twee jaar. Vervolgens is wel gespecificeerd dat indien die periode langer is dan twee jaar de verkoper aansprakelijk is gedurende de tijd dat de digitale inhoud of dienst volgens de overeenkomst dient te worden geleverd. ${ }^{54}$

Lidstaten kunnen een langere termijn invoeren ten aanzien van de duur van de aansprakelijkheid. Dat is goed nieuws voor consumenten in Nederland, want op dit moment kent de consumentenkoop geen vaste periode voor de aansprakelijkheid. Voor duurzame goederen die bijvoorbeeld vijf jaar of langer mee zouden moeten gaan geldt dat bekeken moet worden of de consument

50. Spanjaard (2019, p. 119) signaleert in zijn bespreking van de nieuwe Richtlijn consumentenkoop dat een algemene disclaimer niet zal volstaan en adviseert het laten ondertekenen van een instemmingsformulier.

51. Art. 8 lid 1 onder a en b Richtlijn (EU) 2019/770

52. Verordening (EU) $2016 / 679$ van het Europees Parlement en de Raad van 27 april 2016 betreffende de bescherming van natuurlijke personen in verband met de verwerking van persoonsgegevens en betreffende het vrije verkeer van die gegevens en tot intrekking van Richtlijn 95/46/EG, PbEU 2016, L 119/1-88.

53. Overweging 48 Richtlijn (EU) 2019/770, waar dit wordt toegelicht met enkele voorbeelden.

54. Art. 10 lid 1 en 2 Richtlijn (EU) 2019/771 mocht verwachten dat de desbetreffende zaak gedurende een bepaalde periode probleemloos zou functioneren. ${ }^{55}$ Voor tweedehandsgoederen kan overigens een kortere termijn worden bepaald. ${ }^{56}$

In de Richtlijn digitale inhoud geldt dat, indien het nationale recht een termijn kent waarbinnen de handelaar aansprakelijk kan worden gehouden, die termijn niet minder dan twee jaar mag zijn. Dat impliceert dat door de lidstaten een langere termijn of helemaal geen termijn kan worden bepaald. ${ }^{57}$

\section{Bewijslast ten aanzien van het bestaan van de non- conformiteit ten tijde van de levering}

\section{Bewijslast bij goederen en goederen met digitale elementen}

De handelaar of de verkoper is aansprakelijk indien de goederen, de goederen met digitale elementen of de digitale producten non-conform zijn ten tijde van de levering. ${ }^{58}$ Onder de huidige wetgeving met betrekking tot de consumentenkoop wordt vermoed dat een zaak ten tijde van de aflevering non-conform was, indien de non-conformiteit zich binnen zes maanden na aflevering openbaart. ${ }^{59}$ De consument moet nog wel aantonen dat er sprake is van een conformiteitsgebrek, de verkoper kan vervolgens trachten aan te tonen dat de zaak ten tijde van levering conform was. ${ }^{60}$

De nieuwe Richtlijn consumentenkoop bepaalt in artikel 11 lid 1 dat indien de non-conformiteit binnen een jaar aan het licht komt, de zaak wordt geacht ten tijde van de levering reeds non-conform te zijn geweest. Het woord 'geacht' lijkt erop te wijzen dat het niet langer (slechts) een vermoeden betreft en dat tegenbewijs niet mogelijk is. Uit de zin daarna blijkt evenwel dat tegenbewijs wel mogelijk is en dat het nog steeds een vermoeden betreft. ${ }^{61}$ De termijn waarbinnen dit vermoeden geldt wordt wel aanzienlijk verlengd van zes maanden naar een jaar. De lidstaten hebben bovendien de mogelijkheid om hier een termijn van twee jaar van te maken. ${ }^{62}$

55. Zie hierover M.B.M. Loos, 'Europese harmonisatie van online en op afstand verkoop van zaken en de levering van digitale inhoud (I)', NtEr 2016/3, p. 118: in een eerdere fase bevatte het richtlijnvoorstel op dit punt maximumharmonisatie op het niveau van twee jaar.

56. Art. 10 lid 6 Richtlijn (EU) 2019/771.

57. Art. 11 lid 2 tweede alinea Richtlijn (EU) 2019/770.

58. Art. 11 lid 2 Richtlijn (EU) 2019/770 en art. 10 lid 1 Richtlijn (EU) 2019/771. Ten aanzien van digitale producten die continu gedurende een bepaalde periode moeten worden geleverd geldt dat de digitale producten gedurende die hele periode conform moeten zijn, zie art. 11 lid 3 Richtlijn (EU) 2019/770.

59. Art. 7:18 lid 2 BW, dit is de implementatie van art. 5 lid 3 Richtlijn 1999/44/EG.

60. Over dit bewijsvermoeden zie J. Hijma, 'Consument en non-conformiteitsbewijs', TvC 2013/6, p. 257-261.

61. De eerste zin van art. 11 lid 1 Richtlijn (EU) 2019/771 noemt het woord 'geacht', de tweede zin spreekt evenwel van een 'vermoeden'.

62. Art. 11 lid 1 en 2 Richtlijn (EU) 2019/771. 
Wat betreft goederen met digitale elementen waarbij de koopovereenkomst voorziet in de continue levering van digitale inhoud of een digitale dienst gedurende een bepaalde periode, geldt dat de bewijslast met betrekking tot de vraag of de digitale inhoud of digitale dienst conform was tijdens de overeengekomen periode bij de verkoper ligt indien er gedurende die periode een conformiteitsgebrek aan het licht komt. ${ }^{63}$

Bewijslast bij digitale inhoud en digitale diensten Ten aanzien van digitale inhoud of digitale diensten ligt de bewijslast met betrekking tot de vraag of deze zijn geleverd, bij de handelaar. Indien er is geleverd en binnen één jaar komt een conformiteitsgebrek aan het licht, dan rust de bewijslast met betrekking tot de vraag of de digitale inhoud of dienst conform was ten tijde van de levering eveneens bij de handelaar. Dit geldt ook ingeval de overeenkomst verplicht tot continue levering gedurende een bepaalde periode. Indien gedurende die periode een conformiteitsgebrek aan het licht komt, dan ligt de bewijslast ten aanzien van de vraag of het geleverde conform was gedurende de periode waarin de inhoud of de dienst geleverd wordt bij de handelaar. ${ }^{64}$

Dit is bijvoorbeeld relevant in verband met artikel 16 lid 1 Richtlijn digitale inhoud. Daar is bepaald dat, indien de consument ontbindt omdat de digitale inhoud of de dienst die gedurende een bepaalde periode geleverd dient te worden niet-conform is, de handelaar de betaalde prijs terug moet betalen voor de periode dat de inhoud of de dienst non-conform was. Indien de handelaar kan aantonen dat de digitale inhoud of dienst gedurende een bepaalde periode wel conform was, hoeft de betaalde prijs voor die periode dus niet te worden terugbetaald.

Het zou natuurlijk kunnen dat het niet naar behoren functioneren van digitale inhoud of digitale diensten te wijten is aan de digitale omgeving van de consument. Artikel 12 lid 5 Richtlijn digitale inhoud bepaalt dat de consument een medewerkingsplicht heeft om na te gaan of dit het geval is. Die plicht geldt voor zover dit redelijkerwijs mogelijk en noodzakelijk is en beperkt zich tot de technisch beschikbare middelen die voor de consument het minst ingrijpend zijn. Indien de consument niet meewerkt, terwijl de handelaar de consument wel op duidelijke en begrijpelijke wijze van die plicht op de hoogte heeft gesteld, is het in beginsel aan de consument om te bewijzen dat het conformiteitsgebrek bestond ten tijde van de levering.

\section{Slot}

Vanaf 1 januari 2022 zullen de nieuwe regels in werking moeten treden. Op enkele punten zijn nog keuzes te maken door de nationale wetgever, zodat op dit moment nog niet helemaal duidelijk is hoe de nieuwe situatie eruit zal zien. In deze korte bijdrage heb ik slechts enke- le aspecten belicht, de remedies zijn bijvoorbeeld niet aan bod geweest ${ }^{65}$ en ook de regels die zullen gaan gelden ten aanzien van de wijziging van digitale inhoud of diensten ${ }^{66}$ zijn onbesproken gebleven, maar er zal zeker nog veel over de nieuwe richtlijnen geschreven worden. 